Ethos : Jurnal Penelitian dan Pengabdian kepada Masyarakat, Vol 7, No.1, Januari 2019: 137-142

\title{
Usaha MeningkatKan Kualitas dan Nilai Ekonomi Nata De Coco Bagi Masyarakat Desa Petanahan Melalui Penyuluhan Pembuatan Yang Baik Dan Benar Serta Minuman Ready To Drink Berbasis Nata De Coco
}

\author{
${ }^{1}$ Erminawati, ${ }^{2}$ Wuryatmo Sidik \\ ${ }^{1,2}$ Jurusan teknologi Pertanian, Universitas Jenderal Soedirman \\ E-mail: ${ }^{1}$ erminawati.w@gmail.com
}

\begin{abstract}
BUMDES Sun Coco can be considered as a forum / association of coconut processed products, include VCO and klentik oil processors. Processing of coconut water and liquid-byproduct of VCO into nata de coco has not been provided maximum benefit for farmers. Current situation, coconut water which processed into nata de coco sold still in raw product, at very cheap prices, usually sold at a price of Rp. 1150 $/ \mathrm{kg}$. If the quality of the nata de coco product improved and processed further into ready to drink baverage products, it will increase its selling value and hence will provide business opportunities; which is can be done and accepted by the local community, therefore, it has an impact on employment and the development of SME's in the region. So far, no farmer has processed it further into ready to drink baverages.The implementation of community service activities is considered successful. This can be seen from the innovations of the participants in making ready to drink baverages based on nata de coco which have very good quality and are suitable for sale. This home industry continuity needs to be followed up with marketing guidance and approval from the Ministry of Health.
\end{abstract}

Keywords: Coconut water, Nata de coco, Nata de coco based beverage products, Petanahan-Kebumen.

\begin{abstract}
Abstrak. Pengolahan air kelapa dan produk sampingan cair VCO menjadi nata de coco yang dilakukan masyarakat sekitar Bumdes sun coco desa Petanahan belum memberikan manfaat maksimal. Keadaan saat ini, air kelapa yang diolah menjadi nata de coco dijual masih dalam produk mentah, dengan harga sangat murah, biasanya dijual dengan harga Rp. $1150 / \mathrm{kg}$. Jika kualitas produk nata de coco ditingkatkan dan diproses lebih lanjut menjadi produk minuman siap minum, maka akan meningkatkan nilai jualnya dan karenanya akan memberikan peluang bisnis; yang dapat dilakukan dan diterima oleh komunitas lokal, oleh karena itu, berdampak pada pekerjaan dan pengembangan UKM di wilayah tersebut. Sejauh ini, tidak ada petani yang memprosesnya lebih lanjut ke dalam minuman siap minum. Program pengabdian pada masyarakat PKM Berbasis Riset 2018 ini bertujuan untuk meningkatkan kualitas dan nilai ekonomi nata de coco bagi masyarakat sekitar Bumdes Sun Coco desa Petanahan melalui alih teknologi pembuatan nata de coco secara baik dan benar, dan pembuatan minuman ready to drink berbasis nata de coco. Pelaksanaan kegiatan PKM Berbasis Riset 2018 ini dianggap berhasil, dapat dilihat dari inovasi para peserta dalam membuat minuman ready to drink berbasis nata de coco yang memiliki kualitas sangat baik dan cocok untuk dijual. Kontinuitas kegiatan ini perlu ditindaklanjuti dengan bimbingan pemasaran dan bantuan mendapatkan PIRT. Dengan memanfaatkan air kelapa dan produk sampingan cair VCO menjadi nata de coco, maka akan tercipta lingkungan yang bersih sehingga dengan sendirinya meningkatkan taraf kesehatan masyarakat. Melalui kegiatan ini juga akan terbangun kerjasama kemitraan antara perguruan tinggi dan masyarakat sehingga tujuan pembangunan ekonomi dan kesehatan masyarakat dapat terwujud. Kata kunci : BUMDES, Air kelapa, Nata de coco, Minuman, Petanahan-Kebumen
\end{abstract}




\section{Pendahuluan}

Air kelapa merupakan salah satu komponen buah kelapa. Berbagai produk dapat diolah menggunakan bahan dasar air kelapa, seperti nata de coco, cuka atau minuman berenergi. Sehingga dapat dianggap bahwa air kelapa berpotensi untuk dikembangkan menjaqdi produk minuman yang bernilai gizi, karena kandungan nutrisinya. Kandungan nutrisi air kelapa tergantung pada umur kelapa dan varietasnya. Secara umum per $100 \mathrm{ml}$ mengandung protein $0,2 \mathrm{~g}$, lemak $0,2 \mathrm{~g}$, gula $3,8 \mathrm{~g}$, vitamin $\mathrm{C} 1,0$ $\mathrm{mg}$, asam amino, dan hormon pertumbuhan (Sutarminingsih, 2004). Air kelapa juga mengandung glukosa, senyawa nitrogen dan mineral sehingga sangat baik jika digunakan sebagai media pembuatan nata de coco. Jenis gula yang terkandung glukosa, fruktosa, sukrosa, dan sorbitol.

Nata de coco adalah bahan pangan hasil fermentasi air kelapa dengan bantuan mikroba acetobacter xylinum. Nata de coco mengandung serat tinggidan ini berperan dalam kesehatan karena dapat membantu sistim pencernaan. Produk pangan berbasis nata de coco sudah banyak didapatkan dalam kehidupan sehari-hari dalam berbagai kemasan. Pembuatan nata de coco relative mudah dilakukan sehingga banyak skala rumah tangga yang membuka usaha dibidang ini. Namun untuk membuat nata de coco yang baik secara fisik dan juga memiliki nilai higienis untuk dapat dikonsumsi, diperlukan pengetahuan dan cara-cara produksi yang baik dan benar.

Program Tindakan Masyarakat Berbasis Penelitian (PKM Berbasis Research) bertujuan untuk memberikan wawasan yang lebih luas untuk memanfaatkan peluang dari air kelapa menjadi produk minuman ready to drink berbasis nata de coco, memberikan pengetahuan tentang potensi nata de coco sebagai minuman fungsional, dan memberikan keterampilan bagi masyarakat terhadap pengolahan makanan berdasarkan nata de coco serta meningkatkan jenis bisnis prosesor VCO untuk meningkatkan tingkat ekonomi mereka. Program pengabdian pada masyarakat ini dilakukan di desa Petanahan, Kabupaten Kebumen selama 8 bulan mulai dari Maret hingga Oktober 2018. Target audiens dari kegiatan ini adalah para pengolah VCO di bawah BUMDES sebagai prioritas. Sejauh ini air kelapa yang merupakan hasil sampingan dari pengolahan minyak kelapa digunakan untuk membuat nata de coco. Nata de coco yang mereka hasilkan dijual sangat murah sekitar Rp. 1150 / kg (Sarijan, 2018, Pers, komunikasi), selain itu kualitasnya juga perlu ditingkatkan. Mereka tidak memprosesnya lebih jauh ke dalam minuman siap minum. Diversifikasi siap minum baverages berdasarkan nata de coco adalah peluang bisnis potensial yang pada gilirannya dapat meningkatkan pendapatan masyarakat.

Berdasarkan permasalahan di atas, perlunya meningkatkan kualitas nata de coco yang dihasilkan melalui pelatihan, konseling dan demplot, hal ini diperlukan untuk meningkatkan nilai ekonomi dan meningkatkan keterampilan masyarakat mengenai pengolahan limbah VCO untuk mendukung program-program untuk melestarikan keunggulan lokal kearifan lokal. Selanjutnya, fokus kegiatan dari program ini adalah limbah cair dalam bentuk air kelapa dan sejauh ini beberapa dari mereka juga mengolah air kelapa menjadi nata de coco tetapi masih membutuhkan sentuhan teknologi untuk meningkatkan kualitas nata de coco . 


\section{Tujuan dan Manfaat}

Program PKM Berbasis Riset ini bertujuan untuk memberikan wawasan yang lebih luas untuk memanfaatkan peluang dari limbah air kelapa menjadi produk minuman ready to drink berbasis nata de coco secara maksimal, memberikan pengetahuan tentang potensi nata de coco sebagai minuman fungsional dan memberikan ketrampilan warga masyarakat terhadap pengolahan pangan berbasis nata de coco serta menambah jenis usaha para pengrajin VCO untuk meningkatkan taraf ekonominya.

Manfaat yang didapat dari pengabdian ini adalah:

1. Para pengrajin VCO dan ibu-ibu sekitar desa Petanahan Kab Kebumen mempunyai wawasan yang lebih luas untuk memanfaatkan peluang dari usaha/industri pangan berbasis nata de coco.

2. Masyarakat dapat mengolah nata de coco menjadi minuman ready to drink berbasis nata de coco

\section{Permasalahan Mitra}

1. Pengolahan nata de coco yang diterapkan masih belum standar

2. Harga nata de coco mentah yang dihasilkan dijual masih terlalu murah

3. Mayarakat belum ada yang memproduksi minuman ready to drink berbasis nata de coco

\section{Pemecahan Masalah}

Fokus kegiatan adalah limbah cair berupa air kelapa dan selama ini sebagian dari mereka juga mengolah air kelapa menjadi nata de coco namun masih memerlukan sentuhan teknologi untuk mendapatkan kualitas nata de coco yang berkualitas.
Kegiatan yang dilakukan adalah;

1. Transfer teknologi dan pendampingan perbaikan mutu pengolahan nata de coco,

2. Penyuluhan tentang GMP pada produksi nata de coco serta transfer teknologi dan pendampingan desain kemasan dan pelabelan

3. Kegiatan Lomba Kreasi Inovatif dari nata de coco

\section{Strategi sasaran}

Peserta dalam kegiatan ini adalah pembuat VCO dan minyak klentik di bawah Badan Usaha Milik Desa (BUMDES) SUN COCO sebagai prioritas serta ibu ibu di desa Petanahan dengan 20 peserta. Para peserta aktif berpartisipasi dalam kegiatan ini baik selama kuliah, diskusi dan saat membuat produk. Peran aktif masyarakat adalah karena mereka sangat membutuhkan informasi terkait penerapan teknologi dalam mengolah air kelapa menjadi nata de coco.

\section{Metode Penelitian}

Program ini dilaksanakan untuk perbaikan mutu produk nata dan kreativitas olahannya sampai diperoleh produk yang siap pasar. Adanya antusias dari pengrajin untuk memproses limbah cair VCO menjadi produk olahan sebaik mungkin dan kesediaan untuk memasarkan produknya sendiri agar produk yang dihasilkan bisa menembus ke pasar yang lebih luas merupakan modal utama dari keberhasilan program ini

Untuk mencapai tujuan tersebut maka disepekati langkah-langkah solusi yang akan dilakukan melalui;
1. Transfer teknologi dan pendampingan perbaikan mutu dan hilirisasi proses berbasis nata sesuai dengan keinginan pasar 
2. Transfer teknologi dan pendampingan inovasi produk minuman ready to drink berbasis nata de coco

Metode pendekatan yang ditawarkan untuk mendukung realisasi program berupa penerapan teknologi melalui pelatihan, dan demplot atau pendampingan dan pemberdayaan masyarakat.

\section{Alih Teknologi}

Alih teknologi dilaksanakan di Ruang pertemuan BUMDES Sun Coco desa Petanahan dengan mengundang pengrajin VCO, kepala desa, seluruh perangkat desa serta tokoh-tokoh masyarakat yang ada. Sebelum dilaksanakan alih teknologi terlebih dahulu dilakukan pre-test untuk mengetahui tingkat pengetahuan dan respon khalayak sasaran terhadap nata de coco. Setelah dilaksanakan alih teknologi kemudian diadakan post test untuk mengetahui efektifitas alih teknologi dalam memperkenalkan pembuatan nata secara baik dan benar serta higines. Alih teknologi dikatakan efektif jika nilai post test lebih besar daripada nilai pre-test.

\section{Demplot pembuatan nata de coco secara baik dan benar serta higines}

Teknik pembuatan nata de coco dan kiat-kiat praktisnya dikenalkan kepada khalayak sasaran melalui demplot pembuatan nata de coco secara baik dan benar. Demplot bertujuan untuk memberikan contoh nyata mengenai cara pembuatan nata de coco secara baik dan benar. Setelah pelaksanaan demplot diharapkan khalayak sasaran menjadi lebih paham cara pembuatan nata de coco secara baik dan benar dan dapat mempraktekkannya sendiri di rumah. Demplot dikatakan berhasil jika peserta sangat antusias mengikuti acara demplot dari awal sampai akhir sehingga mereka betul-betul paham teknik dan kiat-kiat ptaktis pembuatan nata de coco dan dapat berinovasi membuat produk minuman ready to drink berbasis nata de coco. Khalayak sasaran dikatakan terampil jika persentase keberhasilannya minimal 95\%.

\section{Hasil dan Pembahasan}

Sosialisasi teknik pembuatan nata de coco yang baik, benar dan higenis dilaksanakan di Ruang pertemuan BUMDES Sun Coco desa Petanahan di hadiri oleh 20 orang, terdiri dari pengrajin VCO dan perwakilan masing-masing RW yang ada di Desa Petanahan. Sosialisasi juga dihadiri oleh kepala desa yang sekaligus membuka acara kegiatan sosialisasi teknik nata de coco yang baik dan benar. Sebelum sosialisasi dilakukan pretest untuk mengetahui pengetahuan dan reaksi khalayak sasaran terhadap nata de coco. Hasil pretest menunjukkan bahwa semua respondens antusias terhadap kegiatan yang akan dilaksanakan. Semua responden $(100 \%)$ menyatakan bersedia diajari cara pembuatan nata de coco yang baik dan benar. Penyuluhan ini banyak diminati peserta dilihat dari jumlah peserta yang datang $80 \%$ dari target awal. Materi yang disampaikan pembicara pada penyuluhan potensi pengolahan limbah ampas kelapa diminati oleh peserta karena materi yang disampaikan menarik dan teknik penyampaian yang komunikatif sehingga peserta mudah dalam penerimaan materi. Tanggapan masyarakat sebagai dosen sangat positif. Para peserta pelatihan sangat antusias berpartisipasi dalam kegiatan ini yang ditunjukkan oleh jumlah pertanyaan yang diajukan selama diskusi. Mereka juga berlatih langsung mengikuti arahan dari Tim Pengabdi untuk mengolah air kelapa secara langsung sampai akhirnya menjadi produk dalam bentuk minuman 
siap minum berdasarkan nata de coco. Masyarakat juga tertarik dengan teknologi pemrosesan nata de coco yang ditunjukkan oleh jumlah pertanyaan yang diajukan selama diskusi. Mereka juga berlatih langsung mengikuti arahan instruktur pelatihan untuk memproses air kelapa secara langsung sampai akhirnya menjadi produk dalam bentuk siap minum, seperti Gambar 1.

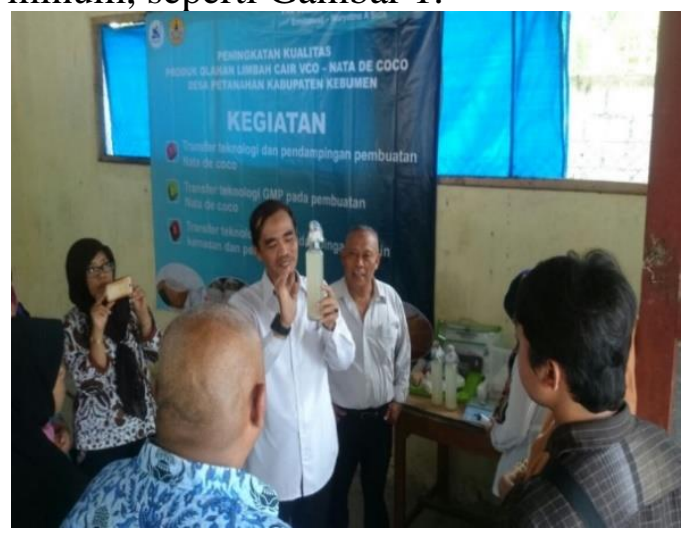

Gambar.1. Transfer Teknologi pembuatan nata de coco yang baik dan
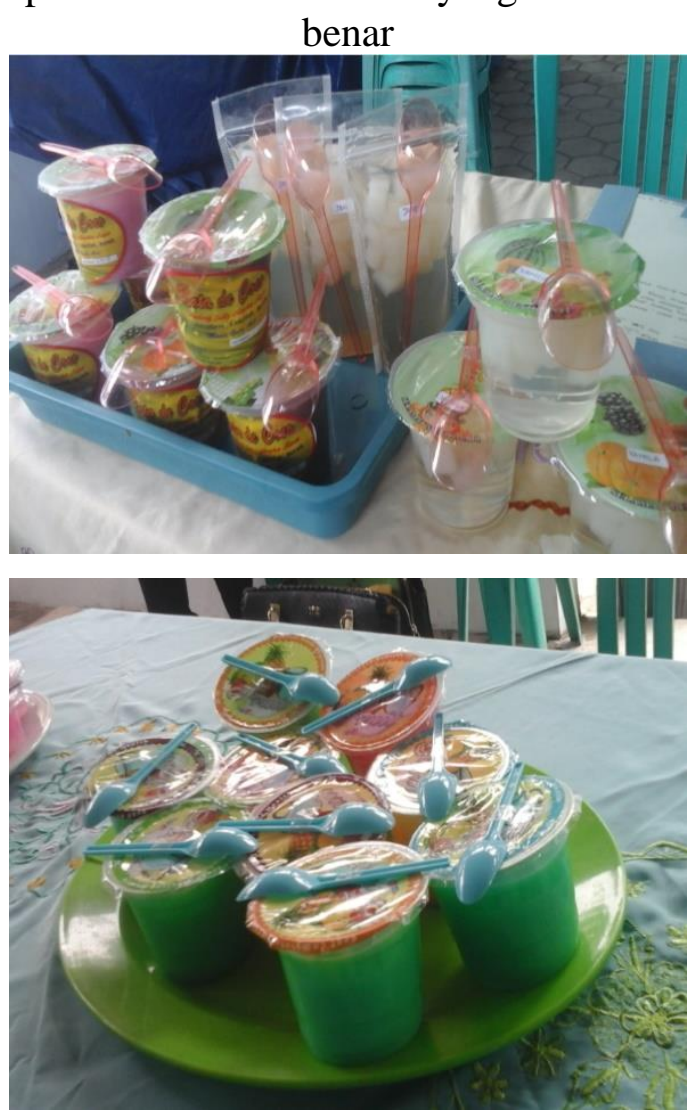

Gambar 2. Hasil Kreasi Inovasi peserta dalam membuat minuman ready to drink berbasis de coco

Selain itu, kegiatan ini dapat mendorong para peserta untuk melakukan satu kegiatan yang dapat meningkatkan bisnis keluargauntuk produk kelapa yang terdiversifikasi. Pengenalan dan pendampingan teknologi pengolahan nata de coco dan minuman ready to drink berbasis nata de coco ini telah menyentuh salah satu aktivitas pengabdian masyarakat dalam hal meningkatkan aktivitas mereka untuk meningkatkan pendapatan keluarga dan juga meningkatkan keterampilan mereka.

\section{Kesimpulan}

Pengenalan pengolahan air kelapa menjadi nata de coco dihargai oleh penduduk desa Patanahan. Upaya yang dilakukan melalui alih teknologi dan praktek langsung membuat nata de coco dan minuman ready to drink berbasis nata de coco, dianggap dapat membangkitkan dan mendorong peserta untuk lebih menambah dan meningkatkan produk olahan dari kelapa. Pengenalan dan penerapan teknologi pemrosesan nata de coco dapat dipercaya tidak hanya untuk meningkatkan keterampilan dan pengetahuan masyarakat, tetapi juga untuk mendorong mereka dalam bidang agribisnis.

\section{Ucapan Terima Kasih}

Terima kasih kepada Kanselir Jenderal Universitas Sudirman melalui Ketua Lembaga Penelitian dan Pengabdian Masyarakat Universitas Jenderal Soedirman untuk dana yang disediakan melalui Dana Penelitian Dana PKM untuk BLU Unsoed 2018 dengan Keputusan Kepala LPPM: No Kep. 2354 / UN23.14 / PN. 01.00 / 2018 
Terima kasih juga kepada masyarakat Petanahan dan BUMDES Sun Coco di desa Petanahan yang telah berpartisipasi dalam kegiatan pengabdian masyarakat ini.

\section{Daftar Pustaka}

Erminawati. 2016. Tepung Ampas Kelapa. Tepung Sehat Kaya serat. Buku TTG

Erminawati, Wuryatmo Sidik dan Riana Listanti.2017. Peningkatan Kualitas dan

Pemasaran Produk Olahan Limbah Padat dan Cair VCO Desa Petanahan Kabupaten Kebumen, Laporan PKM Berbasis Riset BLU Unsoed. LPPM Unsoed.

Erminawati, Wuryatmo Sidik dan Riana Listanti. 2016. Pemanfaatan limbah padat VCO melalui modifikasi pengolahan tepung ampas kelapa untuk diversifikasi pangan sehat. Laporan Penelitian Unggulan Unsoed. LPPM Unsoed.

Sutarminingsih, Ch., 2004. Peluang berusaha nata de coco. Yogjakarta.Kanisiun

Teknologi Pangan UNIMUS. 2006. Aneka Hasil Olahan Kelapa (eBook)

Wuryatmo Sidik, Erminawati dan Riana Listanti. 2016. Pengembangan Pengolahan

Limbah Kelapa Terpadu Desa Petanahan Kecamatan Petanahan Kabupaten Kebumen Sebagai Desa/Kelurahan Inovatif Berbasis Sumber Daya Lokal Kelapa. Laporan Pengabdian KKN Tematik Unsoed. LPPM Unsoed. 